\title{
SCIENTIFIC TERMS IN INDONESIAN MIDWIFERY SCIENCE
}

Maryam Sorohiti ${ }^{1}$

${ }^{I}$ English Language Education Department, Universitas Muhammadiyah Yogyakarta, Indonesia

\section{INFORMASI ARTIKEL:}

\section{Riwayat Artikel:}

Tanggal diterima: September 2020

Tanggal di revisi: September 2020

Tanggal di Publikasi: Oktober 2020

Key Word : literature study, midwifery

terms, scientific, translation

\begin{abstract}
A B S T R A C T
The use of the term midwifery in Indonesian, of course, comes from many foreign language terms, especially English. This can be a separate study that the terms which are made their equivalent in Indonesian must reflect the scientific terms and truth in terms of meaning and grammar. Therefore, this literature research tries to explore some of the terms used in Indonesian by referring to them in Indonesian grammar and meaning in English. In the results of this study, there were three terms that could be studied in terms of language in order to improve understanding of the midwifery term. The three terms were pijat oksitosin (massage aimed at stimulating the release of the hormone oxytocin), ASI eksklusif, and bendungan ASI. The results of this study are expected to provide input for midwifery researchers and academics in Indonesia to further improve the quality of terms of midwifery that may be found in the future.
\end{abstract}

\section{INTRODUCTION}

Often there are debates both small and large in everyday life about the importance of terms and definitions. Definition is so important because, without a clear definition, there is only absolute confusion. This is because the correct definition will be a consistent direction of thought. Clarity of definition provides direction and limits to the extent to which a person develops his ideas in a directed manner and does not confuse readers or listeners. It is necessary to realize that a clear and consistent definition will strengthen an argumentative idea or writing. [1] One thing we must always remember is that everyone can have different understandings. Some writers are so easy to oversimplify a term that is probably used by most people that they don't feel the need to define the term. In this case, it is possible for other people to have a different understanding of a particular term even for a common term. Each term can be used for a specific purpose so it needs to be explained properly.

Language is a very important science for academics. The importance of mastery of the

*Korespondensi: maryamsorohiti@umy.ac.id term to science therefore is also important. In relation to midwifery science, there are terms of midwifery in Indonesian which are deemed not to represent the true meaning of the actual meaning of the term in English. In fact, the language used with correct grammar is a means of transferring knowledge, [2] in the context of learning by teachers to learners, rules made by authorities so that they can be understood well by the public, and research results so that readers can understand them with the accuracy of the message correct.

Grammar is a very important science when transferring knowledge or messages becomes an absolute thing in learning. This is one of the main and first disciplines that must be equipped in any learning, including midwifery education. Grammar allows efficient transmission of information, and hence individuals or groups of individuals without grammar will find it difficult to learn from others about important aspects of the social and physical world. [2]

The consequence of the learning process is 1) 'teachers' who already have good grammar 


\section{The Southeast Asian Journal of Midwifery Vol. 6, No.2, Oktober 2020, p: 58-62

skills and 2) 'learners' who have a desire to have good language skills. These two parties will complement each other in the proper and correct transfer of knowledge. The story of the bombing of the Second World War can be learned about the message that should be conveyed according to its original source. In a history lesson, the bombings that were dropped on two cities in Japan, namely Hiroshima and Nagasaki, illustrate how devastating the effects of this atomic bomb were, with a total death toll of more than 230 thousand people. In fact, the bombing began with a mistranslation.[3] Translating is a complex skill. A translator must interpret the source text, and then put it in another language, keeping the meaning.[4]

The meaning of the term breastfeeding, for example, must be given the proper meaning. Is bottle milk also called breastfeeding? Of course not, because 'breastfeeding' means 'putting the mother's nipple directly into the baby's mouth' and not a bottle. We can compare these two terms: exclusive breastfeeding and exclusive pumping. We must understand that words are a medium of exchange from which understanding comes.[5] If the translation is not done properly, mistakes may occur as seen in the second world war.

Apart from the correct translation, the grammar used by 'intellectuals' in written form must also be used appropriately so that the original message will always be completely received by the recipient of the message. In fact, some of us are accustomed to writing spoken language into scientific articles (journals, assignments, rules, etc.) which creates new problems when the writing is read by others. Take a look at one of the procedures in 60 APN Steps (intra-natal care) written by a group of senior midwives and found on the Internet:
29. Within 1 minute after the baby is born, inject 10 units of oxytocin (intramuscularly) in 1/3 distal lateral thigh (do aspiration before injecting oxytocin)

When we read the clause over and over, we may arrive to a question: Whose thigh is injected according to step number 29? In that step (please think without referring to the previous step), the 'human' is simply called 'baby' so the written 'thigh' will automatically go to the 'baby' thigh. This is the attitude of caution in language that has entered the realm of clinical procedures which in fact may lead to 'human error' which begins with 'the error of the formulator of the procedure'. As with 'rules, laws, policies' which must not have language errors or language errors, clinical procedures must be 'free' from language errors as well. Grammar will always be the key to 'getting the written message'. Therefore, grammar (Indonesian and English) is required to be mastered. Moreover, in midwifery, midwives should verbally correct any misinformation.[6] Based on these aforementioned reasons, this study was conducted to give meaning to some midwifery terms (terminologies) used in Indonesia.

\section{METHOD}

This qualitative study applied a phenomenological approach to analyze the phenomena emerging around the use of midwifery terms in Indonesia. Qualitative research is a research method used to reveal problems in the work life of government, private, community, youth, women, sports, arts and culture organizations so that it can be used as a policy to be implemented for the common welfare. According to Sugiono, problems in qualitative research are temporary, tentative and will develop or change after researchers are in the field.[7] As part of a qualitative study, this literature study 
focused on terms seen from midwifery books in Indonesia. After that, several terms that might be confused with the meaning were separated and finally the terms used in this study were collected in the discussion. The presentation of the analysis was carried out descriptively to narrate the findings of the terms to be discussed.

\section{RESULT AND DISCUSSION}

Of the dozens of terms that have been collected, there are three terms that need synchronization in English and Indonesian. This synchronization is needed to build logic created in Indonesian. The three terms are:

\section{Pijat oksitosin (and other pijats)}

This term needs to be discussed in more depth because the use of the term may have a different meaning from grammar in Indonesian. Note the use of the word 'pijat/massage' which is part of the following phrases:

- Pijat wajah (facial massage) means that the massage is done on the face area.

- Pijat punggung (back massage) means that the massage is done on the back area.

- Pijat telapak kaki (foot massage) means that the massage is done on the soles of the feet.

- Pijat oksitosin? Is this massage done on the oxytocin area?

This basis is the reason why "massage that is done with the aim of releasing the hormone oxytocin' is called pijat oksitosin. This is of course contrary to grammar in Indonesian because, as explained above, massage which is added by mentioning a certain body area is immediately termed 'massage + body area'. It should be used as a separate study that a term will become strange when the term is parsed according to grammar. The term "oxytocin massage" can be categorized as a term that 'has a figurative meaning', that is, a meaning which is not true. This area of the body is converted into hormones, which are expected to be released to relax the person being massaged.

Although the meaning of this term may seem 'different' from other terms that use the word 'massage', this term is already circulating and used by midwifery practitioners in Indonesia. Of course, with an in-depth study, this term can be synchronized with English which does not recognize the term 'oxytocin massage'.

\section{ASI eksklusif}

The second term is 'exclusive breastfeeding' which translates to 'ASI eksklusif'. What is called breastfeeding is inserting the mother's nipple into the baby's mouth. When the term 'ASI eksklusif' is used, it only refers to breastfeeding from birth to 6 months of age. Of course, there are differences in the Indonesian translation from the original meaning in English. 'Exclusive breastfeeding' in English emphasizes breastfeeding by directly inserting the nipple into the baby's mouth. 'ASI eksklusif' does not differentiate the term 'exclusive pumping' so the difference in the meaning of the translation term in Indonesian needs a deeper explanation.

\section{Bendungan ASI}

The mistranslation may happen in the realm of science, including midwifery. For example, if we know the term 'plasenta letak rendah', the term is actually a translation of low-lying placenta. The Indonesian term very clearly describes what occurs in the position of the placenta. However, try to compare it with the term 'Bendungan ASI'. The word 'bendungan' means 'dam' in English. It somehow feels awkward when we refer the 'breast' as a 'dam'. However, this is exactly what happens in Indonesia (Table 1). 
Table 1. The comparison between two terminologies that end up different in translation

\begin{tabular}{|c|c|}
\hline \multicolumn{1}{|c|}{ ENGLISH } & INDONESIAN \\
\hline Low-lying placenta & Plasenta letak rendah \\
\hline $\begin{array}{l}\text { Blocked ducts } \\
\text { during breastfeeding }\end{array}$ & Bendungan ASI \\
\hline
\end{tabular}

When hearing the term 'Bendungan ASI/breast milk dam', a midwife-to-be who has just heard the term will imagine breasts holding so much milk that they may 'enlarge' like a reservoir. This does not illustrate the 'root cause' of why the breast can be problematic (such a dam in English). This can be avoided when the speaker first pronounces the term in English and explains the term (tersumbat = blocked; duktus = ducts; = blocked ducts). After completion, the speaker can inform that the term is known as 'bendungan ASI' in Indonesian. The word 'blocked' in English will give a deeper meaning than the term 'bendungan' which may 'make wrong guesses' in the learner's mind.

Translating means that there are activities to mediate the meaning of the source language into the target language. [8] The ability to translate correctly is an indispensable skill for translators. Translation deals much with tradition. Translation is also about knowledge on cultural exchanges so that translation has become fundamental. As scientific, medical, technological, commercial, legal, cultural or literary purposes, human communication depends heavily on translation and, consequently, interest in the field is also growing.[9] This also happens in midwifery sciences since, for example, midwifery care, including procedures in Indonesia may look upon references that are written in English. Therefore, the translation skills possessed by the one who translates the terms must be in high category to avoid mistranslation.

When the three terms in found in this study are conveyed to the English native speakers, the Indonesian persons must precisely deliver it. This give us understanding that midwifery as a science may give 'awkward' meaning when not translated properly. We may take a look at the untranslatable words. This may occur due to lack of equivalence between languages at this level, for example from English to Indonesia or vice versa. This kind of untranslatability is circumvented by abandoning equivalence at the word level in favor of non-equivalent terms in order to achieve an acceptable degree of equivalence at the text level.[10]

As one of the oldest profession in the world's civilization,[11] midwifery must strive against all obstacles. As a true partner of women, midwives must obtain the best knowledge free of corrupted things that can worsen its existence. Therefore, a small thing like what was illustrated in this study may become a deep consideration for a simple think may become big and cause trouble.

\section{CONCLUSION}

Midwifery is a science that has long been present on earth because one of the elements of human reproduction on this earth is inseparable from the role of midwives long ago. Therefore, the terms used in midwifery in Indonesia should reflect the scientific terms. Hopefully, the results of this literature study will provide input for the development of midwifery in Indonesia.

\section{REFERENCE}

Deniko, R. V., Shchitova, O. G., Shchitova, D. A., \& Lan, N. T. (2015). Learning Terminology in the Age of Higher Education Internationalization: Problems and Solutions. 
Procedia - Social and Behavioral Sciences, 215, 107-

111. doi:10.1016/j.sbspro.2015.11.582

Bloom, P. (2000). Language and thought: Does grammar makes us smart? Current Biology, 10(14), R516R517. doi:10.1016/s0960-9822(00)00582-0

The World's Most Tragic Translation, unsigned article in Quinto Lingo, January 1968, p. 64.

Wongranu, P. (2017). Errors in translation made by English major students: A study on types and causes. Kasetsart Journal of Social Sciences, 38(2), 117-122. doi:10.1016/j.kjss.2016.11.003

Poggenpohl, S., Chayutsahakij, P., \& Jeamsinkul, C. (2004). Language definition and its role in developing a design discourse. Design Studies, 25(6), 579-605. doi:10.1016/j.destud.2004.02.002

Furber, C. M., \& Thomson, A. M. (2010). The power of language: a secondary analysis of a qualitative study exploring English midwives' support of mother's baby-feeding practice. Midwifery, 26(2), 232-240. doi:10.1016/j.midw.2008.05.003

Sugiono. (2005). Memahami Penelitian Kualitatif. Bandung: ALFABETA. p.238

Zainudin, I. S., \& Awal, N. M. (2012). Translation Techniques: Problems and Solutions. Procedia - Social and Behavioral Sciences, 59, 328-334. doi:10.1016/j.sbspro.2012.09.282

El-dali, H. M. (2011). Towards an understanding of the distinctive nature of translation studies. Journal of King Saud University - Languages and Translation, 23(1), 29-45. doi:10.1016/j.jksult.2010.01.001

Kashgary, A. D. (2011). The paradox of translating the untranslatable: Equivalence vs. non-equivalence in translating from Arabic into English. Journal of King Saud University
- Languages and Translation, 23(1), 47-57. doi:10.1016/j.jksult.2010.03.001

Franka, C., \& Ingela, W. (2020). The decade of the midwife!. Sexual \& reproductive healthcare : official journal of the Swedish Association of Midwives, 24, 100518. https://doi.org/10.1016/j.srhc.2020.100518 